УДК $165.75+37.013$

https://orcid.org/0000-0002-4025-6743

\title{
ДОПОВІДІ РИМСЬКОГО КЛУБУ ЯК ЗМІСТОВА І ЦІННІСНА ОСНОВА ДЛЯ СУЧАСНОЇ ОСВІТИ
}

\author{
О.В. Подолякіна, заступник директора з навчальної роботи Бурштинський \\ енергетичний коледж Івано-Франківського національного технічного \\ університету нафти і газу
}

Класичним прикладом інтеграиії сучасної науки у освітній процес є діяльність Римського клубу, матеріали кожної доповіді якого стають невід'ємною частиною освітнього матеріалу багатьох вищих навчальних закладів $i$ особливо тих, які забезпечують освіту дорослих. У контексті загального суспільного глобального розвитку та прогресу освіти і людської самосвідомості, така міжнародна спільнота, як Римський клуб, наголосив на необхідності знайти нові иляхи розвитку світу при виріменні пов'язаних завдань у галузі навколишнього середовища, глобального розвитку та реструктуризації економіки на иляху до сталого розвитку, а також на тому, щьо відповідальність за використання енергї та ресурсів, за навколишнє середовище та соиіальну інтеграцію - ие не просто витрати економіки, иче інвестиції у майбутнє людства. На даний час існує виняткова можливість для держав, бізнесу, громадянського суспільства та окремих осіб об'єднатися у спільних зусиллях, необхідних для вирішення глобальних проблем сьогодення - зміна клімату, зростаюча бідність, втрата біорізноманіття та зникнення видів, виснаження ресурсів, енергетична безпека, деградація середовища, безліч екологічних аварій, зростаюча нестача продовольства та води $i$, за суттю, крах глобальної фінансової системи. Все че значною мірою пов'язано з тією ж основною причиною: нашою марнотратною моделлю споживання, нашими неефективними і марнотратними виробничими системами.

Ключові слова: філософія освіти, освіта дорослих, глобалізація знань, Римський клуб, Організація об'єднаних націй, екологія, демократія, сталий розвиток.

Виконання освітніх завдань у сучасному світі виходять далеко за межі традиційних освітніх інститутів - школи і навіть університетів. Освіта набула високої інтегрованості з наукою (наукові відкриття так швидко оновлюються, що освіта має постійно відстежувати ці зміни), а наука i науковці все більшою мірою беруть на себе виконання не просто просвітницьких функцій, а значною мірою включаються у формування змісту і цінностей освіти дорослих. Класичним прикладом може бути робота Римського клубу (далі просто - Клуб), неформального на початку об’єднання вчених, які досліджували проблеми перспектив розвитку людства, 3 акцентом на формулювання пересторог щодо небезпек ближчого майбутнього. Якщо спочатку результати спільних досліджень членів клубу переважно були 
надбанням політичних еліт, то на сьогодні матеріали кожної доповіді Клубу стають невід'ємною частиною освітнього матеріалу багатьох вищих навчальних закладів і особливо тих, які забезпечують освіту дорослих перепідготовку, стажування та усі інші їі різновиди.

Клуб, заснований світовою науковою елітою, у 1983 році свого часу розпочав підготовку до чергової конференції Клубу за темою „Управління глобальними процесами: привід до надіï”.

Підготовка конференції, на жаль, була перервана кончиною Президента Клубу А. Печчєі, але його друг і співзасновник Клубу О. Кінг зумів довести справу до кінця, провівши конференцію у визначений термін. Це засвідчило, що Римський клуб $є$ не просто зібранням видатних вчених, а набув інституційного статусу - тобто досягає необхідного результату завдяки формалізованій діяльності його членів, незалежно від того, ким саме вони $є$ поза виконанням цих формальних функцій.

Головною подією цієї конференції було прийняття Виконавчим комітетом Римського клубу Хельсінкської декларації „,The Club of Rome Reaffirmations of and Missioni” (Римський клуб - переосмислення місії), яка в доробленому О. Кінгом варіанті була опублікована в журналі „Interdisciplinary Science Reviews” [1]. Декларація складалася з восьми блоків і вступу, в якому було зазначено, що Римський клуб об’єднує близько 100 людей з 40 країн п’яти континентів світу. Клуб вже відіграв значну роль у розумінні людьми й урядами, політичними партіями і профспілками, науковими та релігійними колами глобальних проблем.

Але, на думку авторів декларації, місія Клубу тільки починається. Тому у блоці „Роль Клубу” було сформульовано, що головне завдання Клубу всією своєю діяльністю вести людей, що приймають рішення, а також спільноту до більш глибокого розуміння проблем, вирішення яких надасть довгострокові позитивні ефекти.

Торкаючись концептуальних основ діяльності Клубу, автори декларації підкреслили, що три основних принципи діяльності, прийняті при заснуванні 
Клубу, залишаються, що вони знову демонструють і підкреслюють характер Клубу за намір поширити його географічне й культурне представництво, в тому числі за участю жінок і молоді.

У блоці „Діяльне” була підкреслена значна роль першої доповіді Римського клубу „Межі зростання”, яка розійшлася по світу загальним накладом понад 5 млн примірників і в якій було попереджено, що якщо нічого не буде зроблено, то сформуються достатньо руйнівні процеси як наслідок експоненціального зростання.

За багато років було проведено понад 30 нарад майже на всіх континентах світу (за винятком Австралії), у ході яких виник всесвітній діалог, а дослідження Римського клубу підштовхнули до роздумів і обговорення важливих фундаментальних питань майбутнього, серед яких у блоці „Найближче майбутнє” - управління сучасною спільнотою при пошуках нових підходів до управління динамічними складними системами, ненасильницька спільнота, зростаюча у світі бідність, майбутнє океанів.

Відмічаючи, що 3 дня заснування Клубу глобальна ситуація геополітична, демографічна, технологічна - значно змінилася і тому було зазначено, що світ вступив у перехідний період, який веде до еволюції глобальної спільноти, в межах якої доля кожної країни критичним чином залежить від того, що відбудеться у світі в цілому.

Значна вірогідність того, що можливий кардинальний переділ світової торгівлі, виробництва, влади, вимагатиме негайного розгляду наслідків тих перемін, які зараз відбуваються [2].

Виходячи $з$ цього за одночасного дотримання положень початкового проекту Клубу „Складності людства”, а також з накопиченого досвіду автори Декларації у блоці „Рамки і план дій” зазначили, що парадигми органічного зростання і холістичного розвитку визначають:

- систематичний взаємозалежний розвиток, при якому жоден елемент не може зростати за рахунок інших;

- багатоаспектний розвиток відповідно різних потреб і бажань різних 
регіонів світу;

- гармонійність цілей;

- можливість нейтралізації тих ефектів, що перешкоджатимуть розвитку;

- перенесення акцентів на якість розвитку людства, добробут кожної особистості;

- постійне оновлення 3 переглядом старих цілей як відповідь на виникнення нових цілей.

Разом із тим, у блоці „Деякі питання, що турбують” було зазначено, що на конференції в Хельсінкі рекомендовано на найближчі роки приділити увагу одній головній темі, яку треба шукати серед деяких важливих сфер, що окреслені Виконавчим комітетом:

- ненасильницька спільнота, як протидія загрозі війни, особливо ядерної, за позиції Виконавчого комітету Клубу, що війна - це симптом набагато глибшої хвороби, проявом якої є гонка озброєнь. Водночас в межах цієї проблеми потрібні дослідження інших хвороб спільноти - тероризму, насилля, в тому числі морального, щоб краще зрозуміти причини цих явищ 3 метою взяття їх під контроль без ущемлення політичних та інтелектуальних свобод;

- наслідки зростання чисельності населення, особливо в країнах, що розвиваються, навантаження на природну систему, вплив на міграційні процеси, перерозподіл економічного і політичного впливу, промислового виробництва й трудових ресурсів, накопичення та розподіл багатств, зростання безробіття, на що впливатиме не тільки чисельність населення, а й на технологічні нововведення, що призведе до зростання розриву між багатими і бідними країнами світу, зростання конкуренції щодо земельних ресурсів і розростання мегаполісів у країнах третього світу. При цьому важливою темою можуть стати наслідки і різні темпи зростання чисельності населення в різних країнах;

- наслідки втрат керованості суспільством, що Клуб бачить у зростанні насильства, невміння при наявності величезного бюрократичного апарату у 
вигляді урядових органів та інститутів взяти під контроль рівень забруднювання, процеси опустелення, непродуктивного використання земель, слабкості ООН, слабкості фінансової системи, безсилля перед голодом (зазначимо, що дві останніх позиції, які окреслені 25 років тому, ніби передбачили глобальні фінансові та продовольчі кризи 2007-2009 років).

Ієрархічна структура прийняття рішень не дозволяє, 3 одного боку, максимально наблизити ці рішення до людей, а 3 іншого - створити ефективний міжнародний механізм вирішення основних глобальних проблем, що ставить на порядок денний державний суверенітет.

Ще одна тема - це неадекватність системи ООН з їі масою випадкових спеціалізованих агентств і програм при слабкості регіональних структур.

Обговорюючи цей спектр можливих головних тем Клубу, в Декларації водночас зазначено, що основна тема - майбутнє людства від створення нормального рівня життя для всіх жителів планети до питань якості життя, створення умов, що гарантують гідність особистості та іiі вільний розвиток. При цьому на особливу увагу заслуговує психологія лідерів і людей, що приймають рішення, вплив їх несвідомих надій і бажань на практичні дії. Крім цього, треба зосередити увагу на необхідності розвивати невикористані ресурси інтелекту, фантазії, творчості, що приховані в кожній людині.

У блоці „Соціальні, культурні та політичні наслідки наукових відкриттів і технічних винаходів” зазначено, що, незважаючи на відсутність завдань Клубу 3 проведення наукових досліджень або технологічного прогнозу, його зобов'язання - з’ясувати наслідки інновацій і допомогти тим, хто приймає урядові й виробничі рішення, формувати політику таким чином, щоб взяти під контроль темпи і напрями наукових досліджень і технічних розробок, спрямувавши їх на задоволення потреб усього людства для запобігання того, щоб технологічний прогрес продовжував робити багатих ще багатшими, а бідних ще біднішими.

В останньому блоці Декларації „,Оновлена місія” висловлений оптимізм щодо можливості людства успішно боротися за краще майбутнє, оскільки 
людина має великий запас невикористаних ресурсів, які дадуть можливість розуміти і передбачати, займатися творчістю і мобілізовувати моральні сили, роблячи іiі найціннішим надбанням для будівництва такого майбутнього і для культурної еволюції. Закінчується Декларація висловлюванням, що члени Клубу мають рішучість продовжувати свою місію при потребі передбачення, і в першу чергу щодо майбутнього людства і віри в нього [1].

Таким чином, підсумовуючи результати роботи за 15 років, члени Римського клубу в прийнятій Декларації не тільки фактично звітувалися про проведену роботу 3 вирішення глобальних проблем, 3 намагання стимулювати людство на їх вирішення, а й окреслили основні теми на майбутнє, які, зауважимо, були успішно розкриті в наступних доповідях Римському клубу і доповідях самого Римського клубу.

Як і щодо Гельсинської Декларації, так і після неї на своїх засіданнях Клуб щоразу приймав Декларації відповідно до тих проблем, що обговорювалися. Так, наприкінці жовтня 2009 р. при обговоренні проблем клімату, енергетики та економічного зростання понад 700 учасників зустрічі прийняли Амстердамську декларацію, в якій Римський клуб закликав до негайних дій для запобігання зростаючої загрози катастрофічного зміну клімату.

Клуб наголосив на необхідності знайти нові шляхи розвитку світу при вирішенні пов'язаних завдань у галузі навколишнього середовища, глобального розвитку та реструктуризації економіки на шляху до сталого розвитку, а також на тому, що відповідальність за використання енергії та ресурсів, за навколишнє середовище та соціальну інтеграцію - це не просто витрати економіки, це інвестиції у майбутнє людства. На даний час існує виняткова можливість для держав, бізнесу, громадянського суспільства та окремих осіб об'єднатися у спільних зусиллях, необхідних для вирішення глобальних проблем сьогодення - зміна клімату, зростаюча бідність, втрата біорізноманіття та зникнення видів, виснаження ресурсів, енергетична безпека, деградація середовища, безліч екологічних аварій, зростаюча 
нестача продовольства та води i, за суттю, крах глобальної фінансової системи. Все значною мірою пов'язано з тією ж основною причиною: нашою марнотратною моделлю споживання, нашими неефективними i марнотратними виробничими системами.

Римський клуб наполегливо закликає уряди прийняти угоду щодо змін клімату, що сприятиме енергетичній та економічній безпеці, реагуватиме на зростаючу актуальність ризику катастрофічної зміни клімату.

Цілями узгоджених міжнародних дій щодо клімату повинні бути: прийняти на Конференції ООН з питань клімату в Копенгагені юридично обов’язкові угоди, спрямовані на досягнення стабільного клімату 3 концентрації $\mathrm{CO}_{2}$ в атмосфері не більше 350 мг/кг. Це у першу чергу вимагає дій 3 боку промислово розвинутих країн у поєднанні 3 підвищенням енергоефективності та запобігання зміні клімату в усіх країнах.

Римський клуб закликав також людей та громади у всьому світі до об’єднання своїх зусиль на досягненні сталого майбутнього.

Розвиваючи ідеї Клубу і власну методологію досліджень глобальних проблем, Д. Медоуз із співавторами через 20 років після опублікування приголомшливої монографії „Межі зростання” підготували нову доповідь „За межами: глобальна катастрофа чи стале майбутнє”, в якій знову зазначили, що темпи використання багатьох природних ресурсів i забруднення навколишнього природного середовища вже перевищують допустимі межі. Тому потрібно значно зменшити використання природних ресурсів і забруднення середовища, оскільки може відбутися неконтрольоване скорочення виробництва продуктів харчування, споживання енергії та агропромислового виробництва (зазначимо, що за роки після оприлюднення цього прогнозу його песимістичні висновки не виправдалися).

Водночас автори підкреслили, що таке скорочення не є обов’язковим, якщо людство перейде до практики зменшення чисельності населення (не відбулося) і рівня матеріального споживання (не відбулося) за підвищення 
ефективності використання ресурсів (поступово відбувається). Крім того, торкаючись проблеми формування сталого суспільства, автори висловили думку щодо можливості такого, яка поки що існує.

Слід зазначити, що нині значно поширилося коло установ, які почали займатися моделюванням глобальних проблем, тобто прогнозом розвитку людства з використанням методів системного аналізу [3]. Це Інститут світових ресурсів, США, Вашингтон; Інститут навколишнього природного середовища, Швеція, Стокгольм; Міжнародний інститут технології та управління, Світовий банк; наукові підрозділи ЮНКТАД та ООН; Інститут світового спостереження, США, Вашингтон, на засідання якого автор неодноразово був запрошений i брав участь в обговоренні багатьох доповідей, присвячених конкретним глобальним проблемам; Міжнародний інститут прикладного системного аналізу, Вена, Австрія, у якому розробляються методологічні основи аналізу глобальних проблем, що використовуються для оцінки глобальних змін навколишнього природного середовища, економіки і народонаселення.

Поряд 3 цими дослідницькими центрами автор хотів би коротко окреслити роботу Інституту Рокі Маунтін, незалежного від уряду, політичних партій, ідеологічних і релігійних рухів, який займається дослідженнями, а головне - поширенням своїх знань щодо ефективного використання природних ресурсів, екологічної безпеки, економічного розвитку.

Керівник досліджень і президент цього інституту А.B. Lovins y співавторстві з Е. von Weizsecker, президентом Вуппертальського інституту клімату, навколишнього природного середовища та енергії, Е.H. Lovins, соціологом і політологом підготували у 1997 році доповідь Римському клубу „Фактор чотири. Подвоєння багатства, двократна економія ресурсів” [4, с. 5-6].

Головна ідея доповіді полягає в тому, що вже є технології, які дозволяють кожну одиницю багатства природних ресурсів використати в чотири рази ефективніше. Тобто, автори „хворобу” надмірного споживання ресурсів пропонують „лікувати” за допомогою ефективності і сформулювали 
сім аргументів на користь цього:

Жити краще за рахунок використання ефективних систем освітлення, збереження продуктів, транспорту, випуску якісної продукції, вирощування аграрної продукції.

Менше забруднювати і виснажувати землю при використанні ефективних методів боротьби із забрудненням навколишнього природного середовища, а ефективне використання енергії, високопродуктивне сільське господарство та вирощування лісів могли б позбавити людство від 90\% екологічних проблем сьогодення.

Отримувати прибуток за рахунок зменшення витрат при ефективному використанні ресурсів у виробництві і витрат на їх очищення, оскільки вони не $є$ забруднювачами.

Виходити на ринки $i$ залучати підприємщуів, приваблюючи їх можливістю мати додаткові прибутки за рахунок тільки прибутку, що може надавати ефективне використання ресурсів.

Примножувати використання дефіичтного капіталу за рахунок того, що завдяки запобіганню втрат при використанні ефективних технологій вивільнені гроші можна вкладати у вирішення інших проблем.

Підвищувати безпеку внаслідок зниження ризиків міжнародних конфліктів у боротьбі за ресурси, а також зменшення при цьому витрат на збройні сили.

Бути справедливим і мати більше робочих місць за принципом, що підприємства повинні позбавлятися не від своїх робітників, а від непродуктивних кіловат-годин, тонн і літрів.

Головна мета цієї доповіді - пропонування практичних змін у сфері підвищення ефективності використання ресурсів [5].

Основу їх складають п’ятдесят прикладів чотирикратного підвищення ефективності використання ресурсів, серед яких 20 прикладів революційних перетворень у використанні енергії, 20 - революційного підвищення продуктивності використання матеріалів і 10 прикладів революційного 
підвищення продуктивності транспорту.

Торкаючись питання допомоги з боку ринків для вирішення проблем, автори сформулювали основні принципи еко-капімалізму:

1. Знайди найбільш дешеві способи виконання робіт, а потім сплачуй за них.

2. Вкладай капітал у збереження ресурсів, якщо воно обійдеться дешевше, ніж їх видобуток.

3. Створюй ринки збережених ресурсів.

4. Максимально використовуй обгрунтування мети.

5. Заохочуй дії, які для тебе корисні.

6. Заохочуй жорстку конкуренцію між всіма можливими угодами при інших рівних умовах.

7. Оподатковуй не те, що підходить, а те, що непотрібне.

8. Швидко позбавляйся від неефективного обладнання, замінюючи його на ефективніше [6].

Разом із тим, автори попереджають, що надмірне споживання може випередити революцію в ефективності використання ресурсів і що ВВП відображсає не добробут, а лище обіг товарів $і$ капіталів, що піддються оцінці у грошовому виразі.

Виходячи 3 того, що сучасний стан розвитку світу не може мати довготривалу сталість, Римський клуб нещодавно запропонував трирічну програму „А New Path for World Development”, в якій головний фокус зосереджений на взаємопов'язаних „кластерах”:

1. Зовнішнс середовище і ресурси. Цей кластер пов'язаний із змінами клімату, видобутком нафти, екосистемами і водою.

2. Глобалізація. Кластер пов'язаний із здоров'ям і прибутком, демографічними змінами, робочими місцями, торгівлею та фінансами.

3. Розвиток світу. Кластер сталого розвитку, зростання населення, злиденності, стресу навколишнього природного середовища, виробництва продовольства, здоров'я. 
4. Соціальні трансформації. Кластер соціальних змін, гендерної рівності, етики, релігії, духовності, культури, ідентифікації і поведінки.

5. Мир і безпека. Кластер права, демократії, керованості, солідарності, безпеки і миру.

У межах кожного 3 цих кластерів проблеми міцно пов’язані і по кожному кластеру проводитимуться зустрічі для обговорення досліджень, отриманих експертами високого рівня [7].

У цілому, слід зазначити, що з початку діяльності Римського клубу іiі оцінка та коментарії щодо окремих доповідей надані у численних публікаціях, в яких зазначається велика роль Клубу у піднятті до світового рівня глобальних проблем, які вимагають вироблення сьогодні, невідкладно, збільшення кількості керівників усіх рівнів, політиків, учених, які розуміють ці проблеми і намагаються їх подолати. Для цього необхідно проводити постійні заходи у режимі освіти дорослих, адже базова освіта керівників дає можливість суттєво і достатньо підвищити їхню компетентність у питаннях управління суспільними процесами у світлі нових перспектив розвитку людства завдяки короткотерміновим навчальним програмам. Доповіді Римського клубу дають вже добре підготовлений i достатньо експериментально перевірений i науково доведений матеріал, що значно зменшує для тих, хто його опановує, необхідність витрат часу і висуває значно більш доступні вимоги до рівня їхньої попередньої освітньої підготовки. Цей матеріал розкриває передусім спільні для всього людства проблеми, що дає підстави говорити не лише про глобалізацію знань, але й про те, що саме ці знання стають універсальною складовою сучасної освіти, i освіти дорослих передусім.

\section{Список використаних джерел}

1. King A. The Club of Rome - Reaffirmations of and Missioni / King A.// Interdisciplinary Science Review. - 2016. - Vol. 11, No. 1. - P. 13-18.

2. Engdahl W. A century of war. Anglo-American oil politics and the New World Order. - Wiesbaden: Dinges \& Frick,2016. -360 p.

3. Bello W. U.S. Foreign Policy? Donald Trump.(How the CIA, bad trade deals, and wanton military intervention caused the social crises that gave us the Donald)//Foreign Policy In Focus, January 6, $2016 . \quad$ - : http://fpif.org/ultimate-blowback-u-s-foreign-policy-donald-trump 
4. Месяц Г.А. От редактора перевода. Фактор четыре: затрат - половина, отдача - двойная. Новый доклад Римскому Клубу : [пер А.П. Заварницына, В.О. Новикова; под ред. Г.А. Месяца]. - М. : Academia, 2000. C. 5-6.

5. Вайнцзеккер Э.,. Фактор четыре затрат - половина, отдача - двойная / Вайцзеккер Э., Ловинс Э., Ловинс Л. - Новый доклад Римскому клубу. - С. 26-28.

6. Ibid., C.203.

7. Club of Rome Programmer on „A New Path for World Development” [Електронний ресурс] // Режим доступу : http : // www.clubofrome.org/eng/new-parh/. P. 1.

\section{References}

1. King A. The Club of Rome - Reaffirmations of and Missioni / King A.// Interdisciplinary Science Review. 2016. - Vol. 11, No. 1. - P. 13-18.

2. Engdahl W. A century of war. Anglo-American oil politics and the New World Order. - Wiesbaden: Dinges \& Frick,2016. -360 p.

3. Bello W. U.S. Foreign Policy? Donald Trump.(How the CIA, bad trade deals, and wanton military intervention caused the social crises that gave us the Donald)//Foreign Policy In Focus, January 6, $2016 . \quad-$ :http://fpif.org/ultimate-blowback-u-s-foreign-policy-donald-trump

4. Mesiats H.A. Ot redaktora perevoda. Faktor cheture: zatrat - polovyna, otdacha - dvoinaia. Novыi doklad Rymskomu Klubu : [per A.P. Zavarnytsыna, V.O. Novykova; pod red. H.A. Mesiatsa]. - M. : Academia, 2000. C. 5-6.

5. Vaintszekker Э.,. Faktor cheture zatrat - polovyna, otdacha - dvoinaia / Vaitszekker Э., Lovyns Э., Lovyns L. - Novii doklad Rymskomu klubu. - C. 26-28.

6. Ibid., C.203.

7. Club of Rome Programmer on „A New Path for World Development” [Elektronnyi resurs] // Rezhym dostupu : http : // www.clubofrome.org/eng/new-parh/. R. 1.

\section{ДОКЛАДЫ РИМСКОГО КЛУБА КАК СОДЕРЖАТЕЛЬНАЯ И ЦЕННОСТНАЯ ОСНОВА ДЛЯ СОВРЕМЕННОГО ОБРАЗОВАНИЯ}

\section{О.В. Подолякина}

Классическим примером интеграции современной науки в образовательный процесс является деятельность Римского клуба, материалы каждого доклада которого становятся неотъемлемой частью образовательного материала многих высших учебных заведений и особенно тех, которые обеспечивают образование взрослых. В контексте общего общественного глобального развития и прогресса образования и человеческого самосознания, такое международное сообщество как Римский клуб отметил необходимость найти новые пути развития мира при решении связанных задач в области окружающей среды, глобального развития и реструктуризации экономики на пути к устойчивому развитию, а также на том, что ответственность за использование энергии и ресурсов, за окружающую среду и социальную интеграцию - это не просто затраты экономики, это инвестиции в будущее человечества. В настоящее время существует уникальная возможность для государств, бизнеса, гражданского общества и отдельных лиц объединиться в совместных усилиях, необходимых для решения глобальных проблем современности - изменение климата, растущая бедность, потеря биоразнообразия и исчезновения видов, истощения ресурсов, энергетическая безопасность, деградация среды, множество экологических аварий, растущая нехватка продовольствия и воды и, по сути, крах глобальной финансовой системы. Все это в значительной степени связано с той же основной причиной: нашей расточительной модели потребления, нашими неэффективными и расточительными производственными системами.

Ключевые слова: философия образования, образование взрослых, глобализация знаний, Римский клуб, Организация Объединенных Наций, экология, демократия, устойчивое развитие. 


\section{REPORTS OF THE CLUB OF ROME AS A CONTENT AND VALUE BASIS FOR MODERN EDUCATION}

\section{Olga Podoliakina}

A classic example of the integration of modern science in the educational process is the activity of the Club of Rome, which report materials become an integral part of the educational material of many higher educational institutions and especially those that provide adult education. In the context of general social global development and the progress of education and human self-awareness, international community such as Rolf emphasized the need to find new ways of developing the world in solving related environmental problems, global development and restructuring of the economy on the path to sustainable development, and also that the responsibility for using energy and resources, for the environment and for social integration is not just the cost of the economy, it is an investment in the future of mankind. At present, there is an exceptional opportunity for states, business, civil society and individuals to unite in the joint efforts needed to address the global challenges of today - climate change, growing poverty, loss of biodiversity and species disappearance, resource depletion, energy security, environmental degradation, a host of environmental accidents, a growing shortage of food and water and, in essence, the collapse of the global financial system. This is largely due to the same main reason: our wasteful consumption pattern, our inefficient and wasteful production systems.

The article provides philosophical comprehension of the consequences of demographic growth, especially in developing countries, the burden on the natural system, the impact on migration processes, the redistribution of economic and political influence, industrial production and labor resources, accumulation and distribution of wealth, the growth of unemployment, which will be affected not only by population but also by technological innovation, which will increase the gap between rich and poor countries, the growth of competition for land resources and roses the megalopolises sprawl in third-world countries. At the same time, the consequences and different rates of population growth in different countries could become an important subject.

Key words: philosophy of education, adult education, globalization of knowledge, Roma club, United nations organization, ecology, democracy, sustainable development. 